\title{
Entre medo e audácia: paradoxos da modernização brasileira
}

\section{Between fear and audacity: paradoxes in Brazilian modernization}

\author{
Regina Horta Duarte \\ Professora, Departamento de História/Universidade Federal de Minas Gerais. \\ Belo Horizonte - MG - Brasil \\ reginahortaduarte@gmail.com
}

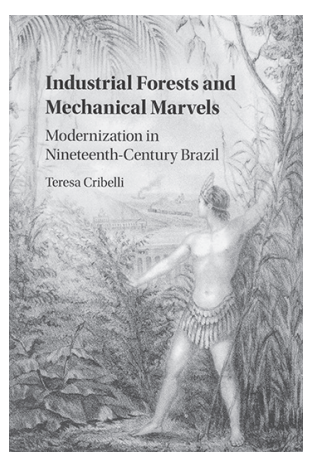

CRIBELLI, Teresa. Industrial forests and mechanical marvels: modernization in nineteenth-century Brazil. New York: Cambridge University Press. 2016. 253p.
Drofessora da Universidade do Alabama (EUA), Teresa Cribelli 1 (2016) relata as notícias esparsas sobre o Brasil que ouviu durante sua infância e adolescência: as habilidades de Pelé, a grandeza da Amazônia, um livro de ficção científica em que esse país se tornara uma potência hegemônica após arrasadora guerra nuclear. Mas foi a maturidade intelectual da historiadora adulta que guiou a curiosidade despertada por fontes jornalísticas sobre a visita de dom Pedro II aos EUA, em 1876.

$\mathrm{O}$ livro Industrial forests and mechanical marvels investiga o Brasil no século XIX, privilegiando a relação de membros das elites políticas, econômicas e intelectuais brasileiras com o fluxo transnacional de ideias, tecnologias e comunicações. Demonstra como entusiastas do progresso e da civilização foram capazes de assumir posturas ativas e ousadas, como construíram caminhos próprios de modernização e inovação tecnológica, em condições históricas e realidades materiais específicas, divididos entre grandes esperanças e os mais arraigados temores.

Duas chaves conceituais conduzem a argumentação. A primeira toma o conceito de modernização como "o nexo de transformações na Europa, América e além, resultante de inovações tecnológicas, burocráticas e econômicas que emergiram nos séculos XVIII e XIX" (p.3). A segunda chave conceitual refere-se à história dos conceitos e das palavras que habitavam as mentes, os escritos e as fala dos homens do passado. Inspirando-se em Leo Marx, Cribelli analisa transformações históricas dos sentidos de palavras como "indústria", "aperfeiçoar", "civilizar", "moralizar", "progresso", em linhas de sofisticada erudição.

Crítica das narrativas triunfalistas da Revolução Industrial inglesa como processo linear de desenvolvimento da mecanização e acumulação de capital, Cribelli revisa certezas estabelecidas sobre a industrialização na América Latina e, mais especificamente, no Brasil. Para tanto, analisa a complexidade da industrialização em seus aspectos socioeconômicos, 
políticos e culturais. A imagem das elites brasileiras reativas e importadoras de modelos externos é desconstruída, dando lugar à trajetória de sujeitos em condições históricas particulares, com destaque para o caldo das tensões sociais que marcaram os últimos anos da escravidão e todas as expectativas e ansiedades pela instituição do trabalho livre.

A autora avalia as posturas de brasileiros frente à modernização, discutindo como assimilaram e reproduziram tecnologia, mas também criaram inovações significativas, especialmente para a produção de café, numa inventividade afinada aos interesses mais urgentes dessa elite. Suas análises da evolução das patentes no Brasil, dos esforços de mecanização agrícola, das propostas de aproveitamento florestal e de renovação dos transportes ferroviários evidenciam como parcelas da elite brasileira estavam conscientes da mecanização decorrente do movimento global de informações, tecnologias e capitais.

O tema da modernização florescia mesclado ao elogio da natureza. A Sociedade Auxiliadora da Indústria Nacional defendia a proteção das florestas como locais onde novas commodities poderiam ser descobertas. Leitores de Humboldt, seus membros assinalavam o valor econômico de flora, fauna e minerais. Seguidores de Lineu, viam a flora como fonte de produtos agrícolas e industriais a explorar. Catalogavam a nação, zelosos do potencial utilitário de sua natureza.

Não obstante o empreendedorismo identificado em ações das elites brasileiras, o desejo de modernização tecnológica conviveu com grandes temores das possíveis consequências que transformações sociais mais profundas poderiam desencadear, numa sociedade baseada no trabalho escravo, orgulhosa de seus sentimentos hierárquicos e constrita por arraigadas práticas culturais e sociais. A obsessão pelo aperfeiçoamento e pela civilização não incluiu desejos de transformação mais radical. Rupturas e mudanças bruscas apareciam como pesadelo, nunca como um sonho. Outro fator limitante, esse sempre lamentado pelas elites modernizantes, eram as imensas dificuldades para estabelecer redes modernas de transporte, ligando as várias áreas do vasto território nacional.

As proposições interpretativas do livro são alicerçadas em ampla pesquisa, com fontes diversificadas. A documentação principal é constituída por "publicações a pedido" e correspondências veiculadas no Jornal do Commercio, entre os anos 1840 e 1889. Tais escritos são sistematicamente relacionados a outras fontes, como textos literários; ensaios de André Rebouças e Joaquim Nabuco, entre outros; relatórios e catálogos das exposições nacionais realizadas nas décadas de 1860 e 1870; periódicos (com destaque para o publicado pela Sociedade Auxiliadora da Indústria Nacional, mas também A Semana Ilustrada e A Revista Ilustrada); pinturas e gravuras artísticas; charges; almanaques; relatos de viajantes pelo Brasil; livros sobre botânica, agricultura e pecuária; manuais sobre maquinários, madeiras, plantas; dicionários de época, discursos diversos. A abordagem das fontes é metódica e diligente, com destaque para as análises da iconografia. Entre as pinturas e charges reproduzidas na edição, nenhuma aparece como mera ilustração. O texto da autora dialoga com cada uma delas, desdobra seus sentidos e intenções, analisando-as como eventos históricos da época em que foram produzidas e veiculadas.

No que diz respeito ao diálogo historiográfico, o leitor brasileiro sente falta de uma interação mais fundamentada da autora com a produção nacional. Dessa forma, a alegada predominância da interpretação das elites brasileiras oitocentistas como hostis à 
industrialização, assim como da incompatibilidade entre tecnologia e trabalho escravo não se sustentam frente a uma revisão bibliográfica mais minuciosa. A historiografia brasileira sobre o século XIX e sobre a escravidão tem experimentado grande renovação, desde os anos 1980, e vai muito além da visão do jornalista Jorge Caldeira, biógrafo de Mauá, ou pelo filme inspirado nessa obra, dirigido por Sérgio Resende, ambos citados por Cribelli como exemplos da visão tradicional sobre industrialização e tecnologia no Brasil.

O livro de Cribelli, com sua escrita elegante e densa, é leitura obrigatória e proveitosa para os estudiosos do Segundo Reinado no Brasil. A edição traz notas de rodapé, agradando especialmente aos leitores que desejam acompanhar mais facilmente as citações de cada página, sem ter que procurá-las a todo momento no fim do livro, como ocorre no caso de notas finais.

Essa é, sobretudo, uma obra útil para pensar os desafios do presente, já que as elites brasileiras contemporâneas parecem manter a postura de almejar a modernidade sem, contudo, dispor-se a enfrentar a urgência de transformações sociais. E talvez a análise desse traço de nossa cultura política - essa contraditória fricção entre o desejo e o temor da transformação - seja uma de suas contribuições mais inquietantes.

\section{REFERÊNCIA}

CRIBELLI, Teresa.

Industrial forests and mechanical marvels: modernization in nineteenth-century Brazil. New York:

Cambridge University Press. 2016. 